\title{
Efektivitas pembelajaran daring matematika menggunakan google classroom selama pandemi COVID -19
}

\author{
Ermawati $^{*}$, Ketut Sarjana ${ }^{2}$, Baidowi $^{2}$, Nyoman Sridana ${ }^{2}$ \\ ${ }^{1}$ Mahasiswa Pendidikan Matematika, FKIP, Universitas Mataram, Mataram \\ ${ }_{2}^{2}$ Pendidikan Matematika, FKIP, Universitas Mataram, Mataram \\ werma818@gmail.com
}

Diterima: 17-10-2021; Direvisi: 26-10-2021, Dipublikasi: 30-10-2021

\begin{abstract}
This study aims to determine the effectiveness of online learning using google classrooms during the Covid19 pandemic in the Mathematics subject focusing on trigonometric equations in class XI MIPA SMA Negeri 1 Selong. This research is quantitative descriptive. The population in this study were all class XI MIPA taught using google classroom. The research sample was selected using cluster random sampling technique, namely class XI MIPA 1 and XI MIPA 2 measuring 70 students. The data collection technique used was the provision of post-test and questionnaire distribution after the students were treated. The research indicator, namely online learning using google classroom, is said to be effective if the student learning outcomes with a percentage of classical completeness $\geq 85 \%$ and student responses are positive to online learning using google classroom. Based on the results of descriptive statistics, if seen from the classical completeness, it was obtained that 60 students were said to have completed their learning or equal to $85,71 \%, 10$ students who did not complete their studies or equal to $14,29 \%$ and seen from the students' responses to online learning using google classroom 11 students responded very positive or equal to $15,71 \%, 57$ students responded positively or equal to $81,43 \%, 2$ students responded negatively or equal to $2,86 \%$, and no students responded very negatively. Based on the results of the research, online learning using google classroom was effective during the covid-19 pandemic in class XI MIPA SMA Negeri 1 Selong in the 2020/2021 school year.
\end{abstract}

Keywords: effectiveness; online learning; google classroom

\begin{abstract}
Abstrak
Penelitian ini bertujuan untuk mengetahui efektivitas pembelajaran daring menggunakan google classroom selama pandemi covid-19 pada mata pelajaran matematika peminatan materi persamaan trigonometri kelas XI MIPA SMA Negeri 1 Selong. Penelitian ini merupakan penelitian deskriptif kuantitatif. Populasi dalam penelitian ini adalah seluruh kelas XI MIPA yang diajar menggunakan google classroom. Sampel penelitian dipilih menggunakan teknik cluster random sampling yakni kelas XI MIPA 1 dan XI MIPA 2 berukuran 70 siswa. Teknik pengambilan data yang digunakan adalah pemberian post-test dan penyebaran angket setelah siswa diberi perlakuan. Indikator penelitian yaitu pembelajaran daring menggunakan google classroom dikatakan efektif jika hasil belajar siswa dengan presentase ketuntasan belajar klasikal $\geq 85 \%$ dan respon siswa positif terhadap pembelajaran daring menggunakan google classroom. Berdasarkan hasil statistik deskriptif, jika dilihat dari ketuntasan klasikalnya diperoleh 60 siswa dikatakan tuntas belajarnya atau sebesar 85,71\%, 10 siswa yang tidak tuntas belajarnya atau sebesar 14,29\% dan dilihat dari respon siswa terhadap pembelajaran daring menggunakan google classroom terdapat 11 siswa merespon sangat positif atau sebesar 15,71\%, 57 siswa merespon positif atau sebesar 81,43\%, 2 siswa merespon negatif atau sebesar $2,86 \%$, serta tidak ada siswa merespon sangat negatif. Berdasarkan hasil penelitian maka pembelajaran
\end{abstract}


daring menggunakan google classroom efektif selama pandemi covid-19 di kelas XI MIPA SMA Negeri 1 Selong tahun ajaran 2020/2021.

Kata Kunci: efektivitas; pembelajaran daring, google classroom.

\section{PENDAHULUAN}

Pemerintah melalui Kemendikbud telah menerbitkan Surat Edaran Mendikbud Nomor 4 Tahun 2020 tentang Pelaksanaan Pendidikan dalam Masa Darurat Corona Virus Disease (COVID-19) menyampaikan agar proses belajar dari rumah dilaksanakan melalui pembelajaran daring/ jarak jauh. Menghadapi situasi ini, e-learning atau pembelajaran daring (dalam jaringan) mulai dilirik oleh instansi pendidikan dalam membantu proses belajar dari rumah.

Hanum (2013) menyebutkan e-learning adalah cara baru pembelajaran dengan akses internet untuk meningkatkan lingkungan belajar tanpa harus datang ke ruangan kelas, dapat diakses dimana saja, dan kapan saja selama memiliki jaringan internet. Beberapa media e-learning yang sudah diciptakan untuk menunjang proses pembelajaran daring antara lain: Schoology, Edmodo, Moodle, Claroline, dan Google Classroom.

Hasil observasi dan wawancara dengan salah seorang guru matematika di SMA Negeri 1 Selong diperoleh bahwa sebagian besar guru dan siswa sudah memiliki perangkat yang menunjang pembelajaran daring, pembelajaran jarak jauh dilaksanakan dengan memanfaatkan aplikasi pembelajaran daring, untuk mata pelajaran matematika khususnya matematika peminatan kelas XI pembelajaran daring menggunakan aplikasi Google Classroom.

Waryanto (2006:15) mengungkapkan bahwa keuntungan dari pembelajaran daring adalah dapat digunakan untuk menyampaikan pembelajaran tanpa dibatasi ruang dan waktu, dapat menggunakan berbagai sumber yang sudah tersedia di internet, dan bahan ajar relatif mudah untuk diperbaharui serta dapat meningkatkan kemandirian siswa dalam proses pembelajaran. Selain itu, kelebihan pembelajaran daring menurut Soekartawi dan setyoningsih (2015:51) diantaranya; 1) dapat digunakan untuk berkomunikasi oleh guru dan siswa tanpa dibatasi ruang dan waktu, 2) guru dan siswa dapat saling menilai sampai sejauh mana materi dipelajari melalui petunjuk belajar yang terstruktur dan terjadwal, 3) siswa dapat me-review ulang bahan ajar setiap saat, 4) dapat mencari referensi tambahan terkait materi secara lebih mudah, 5) siswa lebih aktif 
dalam mengkonstruk pembelajaran sendiri, dan 6) penggunaan pembelajaran daring relatif lebih efisien. Walaupun demikian adanya, pemanfaatan internet untuk pembelajaran daring tidak dapat terlepas dari berbagai kekurangan, diantaranya; 1) mengurangi interaksi antar guru dengan siswa maupun antar sesama siswa, 2) menuntut guru untuk mengetahui pembelajaran berbasis $I C T, 3)$ kurangnya tenaga pengajar yang memiliki keterampilan teknologi, dan 4) kurangnya penguasaan bahasa komputer. Hasil penelitian Hikmatiar dkk. (2020:86) menunjukkan bahwa penggunaan google classroom sebagai media pembelajaran dapat meningkatkan hasil belajar dan minat siswa dalam belajar serta menumbuhkan sikap kreatif pada siswa. Mustakim (2020) juga menyatakan bahwa siswa menilai pembelajaran matematika menggunakan media online sangat efektif. Walaupun demikian adanya, apakah pembelajaran daring menggunakan google classroom yang dilakukan oleh SMA Negeri 1 Selong masih efektif, dikatakan efektif apabila hasil belajar dapat memenuhi ketuntasan klasikal $\geq 85$ dan respon siswa positif terhadap pembelajaran daring menggunakan google classroom.

\section{METODE PENELITIAN}

Populasi dalam penelitian ini adalah seluruh siswa kelas XI MIPA SMA Negeri 1 Selong tahun ajaran 2020/2021 yang terdiri dari 5 kelas. Sampel dipilih dengan teknik cluster random sampling karena semua kelas homogen. Setelah dilakukan cluster random sampling didapatkan sampel penelitiannya adalah kelas XI MIPA 1 dan kelas XI MIPA 2 berukuran 70 siswa. Adapun langkah-langkah kegiatan pembelajaran daring menggunakan google classroom yang digunakan selama penelitian (Lakawa, 2020) yaitu 1) mempersiapkan perangkat-perangkat yang dibutuhkan dalam pembelajaran seperti laptop, android, dan jaringan internet; 2) guru login ke laman google classroom menggunakan email dan mengirim materi atau bahan ajar serta penugasan atau kuis pada menu tugas kelas; 3)guru meminta siswa mempelajari materi, mengerjakan tugas dan mendiskusikan materi yang belum dipahami melalui menu forum komentar kelas maupun komentar pribadi terkait materi; 4) memberikan respon terkait pertanyaan atau komentar yang disampaikan siswa melalui menu forum atau menu komentar pribadi; 5) meminta siswa mengumpulkan tugas melalui link pengumpulan tugas yang sudah dikirim pada menu tugas kelas; 6) jika tidak ada pertanyaan lagi pada menu komentar, maka guru menyimpulkan siswa sudah memahami materi; 7) memberi kesimpulan, 
mengapresiasi, memberikan penilaian tugas dan memberi penguatan dalam bentuk verbal kepada siswa atas partisipasi dalam pembelajaran agar tetap semangat dan termotivasi.

Instrumen yang digunakan adalah post-test bentuk pilihan ganda dengan 24 butir dan angket respon siswa dengan 12 butir pernyataan. Formula Aiken's V untuk menghitung koefisien validitas isi oleh Saifuddin dalam Kartowagiran (2018:104) dengan rumus:

$$
\begin{gathered}
V=\frac{\sum s_{i}}{[n(c-1)]} \\
s_{i}=r_{i}-l_{o}
\end{gathered}
$$

Keterangan:

$\mathrm{V}=$ indeks validitas butir;

$l_{0}=$ skor kategori terendah;

$\mathrm{c}=$ skor kategori tertinggi;

$r_{i}=$ skor butir ke-i yang diberikan ahli;

$\mathrm{n}=$ banyak ahli

Acuan pengelompokan hasil validitas isi dapat dilihat dalam tabel sebagai berikut.

Tabel 1. Kriteria Validitas Isi

\begin{tabular}{cc}
\hline Indeks Validitas & Kriteria Validitas \\
\hline $0,80<V \leq 1,00$ & Sangat tinggi \\
$0,60<V \leq 0,80$ & Tinggi \\
$0,40<V \leq 0,60$ & Cukup \\
$0,20<V \leq 0,40$ & Rendah \\
$0,00 \leq V \leq 0,20$ & Sangat Rendah \\
\hline
\end{tabular}

(Sumber: Saifuddin dalam Kartowagiran , 2018: 104)

Adapun kriteria minimal instrumen dapat dikatakan baik untuk digunakan mengambil data adalah jika indeks validitas lebih dari 0,40.

Uji reliabilitas butir angket dilakukan menggunakan rumus Alpha Cronbach's. Sedangkan uji reliabilitas soal tes dilakukan menggunakan metode $K-R 20$. Untuk menghitung indeks daya pembeda butir soal tes yaitu data diurutkan dari nilai tertinggi sampai terendah, kemudian diambil 50\% dari kelompok yang mendapat nilai tinggi dan $50 \%$ dari kelompok yang mendapat nilai rendah. Thomas dan Dawson dalam Kartowagiran (2018) mengatakan bahwa butir soal yang baik adalah butir soal yang mempunyai indeks daya beda $\geq 0,40$. 
Teknik analisis data yang digunakan adalah analisis statistik deskriptif, untuk menganalisis data hasil belajar matematika siswa dan respon siswa menggunakan google classroom. Penilaian hasil belajar matematika siswa akan dianalisis menggunakan ketuntasan belajar klasikal. Kriteria keefektifan dalam indikator ini ada 2 yaitu ketuntasan hasil belajar secara klasikal $\geq 85 \%$ dari seluruh siswa yang tuntas dan respon siswa positif terhadap pembelajaran daring menggunakan google classroom.

Kategori seorang siswa dikatakan tuntas belajar apabila memiliki nilai minimal 75 . Menurut Depdikbud dalam (Trianto, 2010: 241) mengatakan bahwa siswa dikatakan tuntas belajarnya jika terdapat $85 \%$ dari jumlah siswa memperoleh nilai KKM yang ditetapkan sekolah. Adapun untuk perhitungan ketuntasan secara klasikal disajikan dengan rumus:

$$
\begin{gathered}
\text { Ketuntasan klasikal }=\frac{\text { jumlah siswa yang mencapai nilai minimal } K K M}{\text { jumlah siswa }} \times 100 \% \\
\text { dengan } K K M=75
\end{gathered}
$$

Selanjutnya, dalam keperluan analisis deskriptif terkait respon siswa diperoleh dari angket respon siswa yang diukur menggunakan skala likert dengan rentang skor dari satu sampai empat. Skor rata-rata respon siswa dapat dihitung dengan rumus:

$$
\text { Skor rata }- \text { rata }(\bar{x})=\frac{\sum_{i=1}^{4}\left(n_{i} \cdot f_{i}\right)}{N}
$$

Keterangan:

$f_{i}=$ bobot skor siswa yang menjawab kategori ke-i;

$n_{i}=$ skor kategori ke-i;

$N$ : Banyak seluruh siswa;

$\mathrm{i}=1,2,3,4$;

Tabel kategori skor rata-rata untuk respon siswa terhadap pembelajaran daring menggunakan google classroom dapat disajikan dalam tabel sebagai berikut.

Tabel 2. Kategori Penskoran Respon Siswa

\begin{tabular}{cc}
\hline Skor Rata-rata $(\bar{x})$ & Kategori \\
\hline $3<(\bar{x}) \leq 4$ & Sangat Positif \\
$2<(\bar{x}) \leq 3$ & Positif \\
$1<(\bar{x}) \leq 2$ & Negatif \\
$0<(\bar{x}) \leq 1$ & Sangat Negatif \\
\hline & (Sumber: Nasoetion, 2007:12).
\end{tabular}




\section{HASIL DAN PEMBAHASAN}

Penelitian ini dilakukan dengan tujuan untuk mengetahui efektivitas pembelajaran daring menggunakan google classroom selama pandemi covid-19 pada mata pelajaran matematika peminatan materi persamaan trigonometri kelas XI MIPA (Haryati, 2018). Sebelum instrumen post-test dan angket digunakan untuk mengambil data terlebih dahulu dilakukan uji instrumen. Uji instrumen post-test pilihan ganda dan angket respon siswa bentuk uji yang digunakan adalah uji validitas isi yang dilakukan oleh 2 validator ahli yaitu Surya Mayadi, S.Pd, M.Sc selaku Dosen Matematika Universitas Hamzanwadi Pancor dan H. Maftuhin, S.Pd, M.Pd selaku guru matematika SMA Negeri 1 Selong.

\subsection{Hasil Uji Instrumen}

Untuk angket respon siswa juga divalidasi dengan membuat lembar validasi instrumen untuk mendapatkan saran dan perbaikan dari ahli sebagai validator. Berdasarkan hasil dari validitas isi menggunakan Aiken's V yang dilakukan oleh 2 validator ahli untuk instrument angket respon siswa, dari 12 pernyataan dengan 7 pernyataan terkait dengan penerimaan siswa pada kemudahan Google Classroom dan 5 pernyataan terkait dengan performa Google Classroom dinyatakan layak digunakan untuk mengambil data tanpa revisi. Rincian hasil dari validitas isi butir pernyataan pada angket respon siswa yang dilakukan oleh 2 validator ahli dapat dilihat pada tabel berikut.

Tabel 3. Hasil Validitas Isi Butir Angket

\begin{tabular}{cccc}
\hline Kriteria Validitas & Nomor Butir Pernyataan & $\begin{array}{c}\text { Jumlah } \\
\text { Butir }\end{array}$ & Persentase (\%) \\
\hline Sangat Tinggi & $1,2,3,4,6,7,8,9,10,11$ & 10 & 83 \\
\hline Tinggi & 5,12 & 2 & 17 \\
\hline Cukup & - & 0 & 0 \\
\hline Rendah & - & 0 & 0 \\
\hline Sangat Rendah & - & 0 & 0 \\
\hline
\end{tabular}

Sedangkan soal post-test divalidasi dengan membuat lembar validasi instrumen untuk mendapatkan saran dan perbaikan dari ahli sebagai validator. Hasil validasi isi dari 2 validator ahli kemudian dianalisis menggunakan Aiken's V. Rincian hasil validitas isi soal post-test pilihan ganda yang dilakukan oleh 2 
validator ahli berdasarkan hasil koefisien Aiken's V dapat dilihat pada tabel berikut.

Tabel 4. Hasil Validitas Isi Soal Post-test Pilihan Ganda

\begin{tabular}{cccc}
\hline Kriteria Validitas & Nomor soal & Jumlah soal & Persentase (\%) \\
\hline Sangat Tinggi & $1,2,3,4,5,6,7,8,9,10,11,12,13,14,15,1$ & 24 & 100 \\
Tinggi & $6,17,18,19,20,21,22,23,24$ & & \\
Cukup & - & 0 & 0 \\
Rendah & - & 0 & 0 \\
Sangat Rendah & - & 0 & 0 \\
\hline
\end{tabular}

Adapun untuk daya pembeda butir soal tes dan tingkat kesukaran soal terdapat 20 butir soal (kecuali soal nomor 12, 14, 16, dan 18) yang dapat digunakan sebagai instrumen yang baik untuk mengambil data.

Berdasarkan uji intsrumen soal post-test di atas dari 24 soal yang diuji coba terdapat 4 soal yang tidak memenuhi kriteria daya pembeda dan tingkat kesukaran soal yaitu soal nomor 12, 14, 16 dan 18. Jadi dalam penelitian ini, soal tes yang dapat dijadikan sebagai instrumen penelitian berjumlah 20 soal yaitu soal nomor 1, 2, 3, 4, 5, 6, 7, 8, 9, 10, 11, 13, $15,17,19,20,21,22,23$, dan soal nomor 24. Namun, soal yang digunakan untuk mengambil data dalam penelitian ini adalah soal yang berkaitan dengan sub materi yang diajarkan saja yaitu soal pada indikator 4 terkait persamaan kuadrat trigonometri (soal nomor 15, 19, 20, dan 23), soal pada indicator 5 terkait menyelesaikan permasalahan trigonometri dalam kehidupan sehari-hari (soal nomor 24), serta soal pendukung prasyarat indikator 4 dan 5 (soal nomor 2, 4, 11,13, dan 17). Jadi, total keseluruhan soal yang digunakan dalam mengambil data ada 10 soal yaitu soal nomor $2,4,11,13,15,17$, 19, 20, 23 dan soal nomor 24 .

\subsection{Statistik deskriptif}

Analisis statistik deskriptif digunakan untuk menganalisis data hasil belajar matematika siswa dan angket respon siswa yang telah diperoleh. Jika kedua kriteria keefektifan yaitu ketuntasan belajar secara klasikal $\geq 85 \%$ dan respon siswa berada dalam kategori positif maka pembelajaran daring menggunakan google classroom efektif diterapkan di SMA Negeri 1 Selong. 


\subsubsection{Hasil Belajar Matematika Siswa}

Data diolah sehingga diperoleh hasil belajar matematika siswa pada tabel berikut.

Tabel 5. Analisis Hasil Belajar

\begin{tabular}{cccc}
\hline Interval & Banyak Siswa & Persentase (\%) & Kategori \\
\hline $75<X \leq 100$ & 60 & $85,71 \%$ & Tinggi \\
$50<X \leq 75$ & 3 & $4,29 \%$ & Cukup \\
$25<X \leq 50$ & 4 & $5,71 \%$ & Kurang \\
$0 \leq X \leq 25$ & 3 & $4,29 \%$ & Rendah \\
\hline
\end{tabular}

3.2.2 Ketuntasan Belajar secara Klasikal

Berdasarkan kriteria ketuntasan minimal (KKM) yang berlaku di SMA Negeri 1 Selong yaitu 75, maka tingkat pencapaian ketuntasan hasil belajar matematika secara klasikal pada kelas yang diajar dengan pembelajaran daring menggunakan google classroom dapat dilihat dalam tabel berikut.

Tabel 6. Ketuntasan Belajar Secara Klasikal

\begin{tabular}{cccc}
\hline \multirow{2}{*}{ Skor Post-tes $(x)$} & Kriteria & Banyak Siswa (N) & $\begin{array}{c}\text { Persentase Ketuntasan } \\
\text { Klasikal (\%) }\end{array}$ \\
\cline { 3 - 4 } & & 10 & 14,29 \\
$75 \leq x<75$ & Tidak Tuntas & 60 & 85,71 \\
Total & Tuntas & 70 & \\
\hline
\end{tabular}

\subsubsection{Deskripsi Respon Siswa}

Analisis hasil respon siswa terhadap pembelajaran daring menggunakan google classroom dapat dilihat pada tabel berikut.

Tabel 7. Analisis Hasil Respon Siswa

\begin{tabular}{cccc}
\hline Skor Rata-rata $(\bar{x})$ & Kriteria & \multicolumn{2}{c}{ Frekuensi } \\
\cline { 3 - 4 } & & $\begin{array}{c}\text { Banyak Siswa } \\
(\mathrm{N})\end{array}$ & Persentase (\%) \\
\hline $3<\overline{\boldsymbol{x}} \leq 4$ & Sangat Positif & 11 & 15,71 \\
$2<\overline{\boldsymbol{x}} \leq 3$ & Positif & 57 & 81,43 \\
$1<\overline{\boldsymbol{x}} \leq 2$ & Negatif & 2 & 2,86 \\
$0<\overline{\boldsymbol{x}} \leq 1$ & Sangat Negatif & 0 & 0 \\
Total & & 70 & \\
\hline
\end{tabular}

Berdasarkan Tabel 6. dan Tabel 7., dapat disimpulkan hasil belajar matematika dengan persentase ketuntasan belajar klasikal sebesar $85,71 \%$ dan respon siswa positif terhadap pembelajaran daring menggunakan google classroom dengan perentase total sebesar 
97,14\% (persentase positif sebesar $81,43 \%$ dan persentase sangat positif sebesar $15,71 \%$ ). Sehingga jika dipandang dari kriteria keefektifan, dapat disimpulkan bahwa pembelajaran daring matematika menggunakan google classroom efektif selama pandemi covid-19 di kelas XI MIPA SMA Negeri 1 Selong. Hal ini sejalan dengan pendapat Diamond (2015: 297) mengemukakan bahwa keefektifan dapat diukur dengan melihat respon siswa terhadap penggunaan media pembelajaran. Jika siswa tidak merespon baik terhadap penggunaan media dalam pembelajaran menyebabkan ia tidak berminat untuk mempelajari materi pelajarannya, maka tidak dapat diharapkan ia akan memperoleh hasil yang baik dalam pembelajaran. Sebaliknya, jika siswa belajar dengan respon yang baik terhadap penggunaan media pembelajaran, maka dapat diharapkan hasilnya akan lebih baik, sehingga penerapan media pembelajaran terhadap pembelajaran efektif untuk diterapkan. Hal ini juga selaras dengan penelitian Nirfayanti \& Nurbaeti (2019) yang menunjukkan bahwa terdapat pengaruh signifikan media pembelajaran google classroom terhadap motivasi belajar yang diukur dari respon terhadap penggunaan google classroom dan hasil belajar dengan rata-rata hasil belajar dalam kategori tinggi dan nilai respon terhadap pembelajaran dengan google classroom dalam kategori sangat baik. Meningkatnya respon dalam menggunakan google classroom terhadap pembelajaran berbanding lurus dengan meningkatnya hasil belajar. Untuk itu dapat diartikan bahwa respon yang baik/positif terhadap penggunaan media pembelajaran dapat mempengaruhi hasil belajar menjadi meningkat.

Selama pelaksanaan pembelajaran daring berlangsung tidak dapat terlepas dari kendala yang ada, di antaranya yaitu; 1) kesulitan mendapat jaringan internet, 2) siswa kurang aktif dalam bertanya terkait permasalahan yang dihadapi, 3) materi yang diberikan tidak dapat dijelaskan seluruhnya secara rinci kepada siswa, dan 4) guru kesulitan dalam mengetahui tingkat pemahaman siswa terhadap materi yang telah diajarkan, serta 5) KKM pada materi persamaan trigonometri menurut peneliti terlalu tinggi untuk diterapkan pada masa darurat covid-19. Hal ini didukung oleh Purwanto (2020: 6) menyatakan bahwa ada beberapa kendala yang dirasakan siswa dan guru pada proses belajar mengajar di rumah adalah para siswa merasa dipakasa belajar jarak jauh tanpa sarana dan prasarana memadai di rumah. Sistem pembelajaran daring memberikan dua sisi yang berlawanan. Di sisi lain membantu lembaga pendidikan untuk tetap dapat 
melaksanakan proses belajar mengajar sampai pandemi ini berakhir, sisi lainnya justru menimbulkan ketimpangan di dalamnya (Setiawan \& Komalasari, 2020: 9).

Harapan dari peneliti berkaitan dengan pembelajaran daring pasca pandemi covid-19 antara lain pembelajaran tatap muka diharapkan dapat dipadukan dengan pembelajaran daring untuk melatih keterampilan guru dan siswa dalam memanfaatkan teknologi dan informasi dan pemanfaatan google classroom dapat dijadikan sebagai alternatif dalam menerapkan pembelajaran daring.

\section{PENUTUP}

Berdasarkan hasil dan pembahasan pada penelitian, jika dilihat dari kriteria keefektifan yang telah ditetapkan, dapat disimpulkan bahwa pembelajaran daring matematika menggunakan google classroom efektif selama pandemi covid-19 di kelas XI MIPA SMA Negeri 1 Selong tahun ajaran 2020/2021.

\section{REKOMENDASI}

a. Bagi siswa

1) Lebih meningkatkan keaktifan belajar dalam merespon guru selama kegiatan pembelajaran berlangsung agar mendapatkan hasil belajar yang memuaskan,

2) Siswa yang terkendala dengan jaringan internet dapat datang sekolah untuk mengerjakan tugas atau ulangan yang diberikan guru di sekolah

b. Bagi guru

1) Memaksimakan materi agar dapat diterima baik oleh siswa hendaknya pemberian materi dapat dilakukan dengan menggunakan video pembelajaran interaktif yang dibuat sendiri oleh guru,

2) Pembelajaran daring menggunakan google classroom dapat dipadukan dengan video conference atau aplikasi daring lainnya agar guru tetap dapat memantau proses pembelajaran,

3) Tetap memberikan materi sebelum penugasan yang dilengkapi cara kerjanya,

4) Tetap mengingatkan siswa jika ada tugas yang diberikan

5) Selalu menanyakan kepada siswa terkait permasalahan yang dihadapi baik melalui forum diskusi maupun pesan pribadi

6) Guru berkoordinasi dengan wali kelas terkait siswa yang tidak aktif selama pembelajaran

7) KKM pada mata pelajaran matematika perlu diturunkan mengingat pembelajaran dilakukan pada masa darurat covid-19.

c. Bagi sekolah 
1) Memberi dukungan fasilitas yang memadai untuk pelaksanaan pembelajaran daring dengan meningkatkan ketersediaan sarana dan prasarana pendukung pembelajaran daring

2) Mengkomunikasikan kepada guru mata pelajaran untuk meninjau kembali KKM mengingat pembelajaran dilakukan pada masa darurat covid-19.

d. Bagi peneliti lain, dapat dijadikan sebagai bahan pertimbangan dalam melakukan penelitian yang lebih luas dan mendalam.

\section{REFERENSI}

Arikunto, S. (2013). Prosedur Penelitian. Jakarta : Rineka Cipta.

Diamond, S. (2015). Eektivitas komunikasi penggunaan media sosial dalam pembelajaran. Jakarta: Aksara Indah.

Hanum, N. S. (2013). Keefektifan E-learning Sebagai Media Pembelajaran (Studi Evaluasi Model Pembelajaran E-learning SMK Telkom Sandhy Putra Purwokerto. Jurnal Pendidikan Vokasi, Volume 3 Nomor 1, 90-102.

Haryati, S. (2018). Matematika Peminatan Paket C Tingkatan V Modul Tema 3: Arsitek Modern. Jakarta : Direktorat Pembinaan Pendidikan Keaksaraan dan Kesetaraan-Ditjen Pendidikan Anak Usia Dini dan Pendidikan Masyarakat-Kementerian Pendidikan dan Kebudayaan.

Hikmatiar , H., Sulisworo, D., \& Wahyuni, M. E. (2020). Pemanfaatan Learning Manegement System Berbasis Google Classroom Dalam Pembelajaran. Jurnal Pendidikan Fisika, Volume 8 Nomor 1, 78-86.

Kartowagiran , B. (2018). Optimalisasi Uji Tingkat Kompetensi di SMK untuk Meningkatkan Soft Skill Lulusan, Laporan Penelitian. Jurnal Vokasional Teknik Mesin, Volume 3 Nomor 2, 101-109.

Kemdikbud. (2013). Salinan Peraturan Menteri Pendidikan dan Kebudayaan Nomor 67 Tahun 2013. Retrieved Desember 15, 2020, from Kemdikbud: https://jdih.kemdikbud.go.id/arsip/Salinan\%20Permendikbud\%20Nomor\%2067\%20Tahun \%202013.pdf

Lakawa, N. (2020). Pembelajaran Moda Daring Menggunakan Google Classroom. Dipetik Januri 31, 2021, dari Guru Berbagi: https://guruberbagi.kemdikbud.go.id/artikel/pembelajaranmoda-daring-menggunakan-googleclassroom/

Mustakim. (2020). Efektivitas Pembelajaran Daring Menggunakan Media Online Selama Pandemi Covid-19 Pada Mata Pelajaran Matematika. Jurnal Pendidikan Islam Vokasi, Volume 2 Nomor 1, 1-12.

Nasoetion, N. (2007). Evaluasi Pembelajaran Matematika Cet.1. Jakarta : Universitas Terbuka.

Nirfayanti, N. (2019). Pengaruh Media Pembelajaran Google Classroom Dalam Pembelajaran Analisis Real Terhadap Motivasi Belajar Mahasiswa. Jurnal Penelitian Matematika dan Pendidikan Matematika, Volume 2 Nomor 2, 50-59.

Purwanto, A. (2020). Studi Eksploratif Dampak Pandemi COVID-19 Terhadap Proses Pembelajaran Online di Sekolah Dasar. Jurnal Bimbingan dan Konseling, Volume 2 Nomor 1, 1-12.

Setiawan, R., \& Komalasari, E. (2020). Membangun Efektifitas Pembelajaran Sosiologi Di Tengah Pandemi Covid-19. Jurnal Ilmiah Penelitian Pendidikan dan Sosiologi, Volume 4 Nomor $1,1-13$. 
Ermawati, dkk.

Efektivitas pembelajaran daring matematika $\ldots$

Trianto. (2010). Mendesain Model Pembelajaran Inovatif-Progresif. Jakarta: Kencana.

Waryanto, N. H. (2006). On-line Learning Sebagai Salah Satu Inovasi Pembelajaran Pythagoras. Jurnal Pendidikan Islam, Volume 2 Nomor 1, 10-23. 